\title{
Adsorption Efficiency and Isotherms of COD and Color Using Limestone and Zeolite Adsorbents
}

\section{Mohd Arif Rosli ${ }^{1}$, Zawawi Daud ${ }^{2 *}$, Halizah Awang ${ }^{3}$, Nur Adila Ab Aziz ${ }^{2}$, Mohd Baharudin Ridzuan², Mahmoud Hijab Abubakar ${ }^{2}$, Mohd Shalahuddin Adnan², Husnul Azan Tajarudin ${ }^{4}$}

\author{
${ }^{1}$ Department of Civil Engineering Technology, Faculty of Engineering Technology, Universiti Tun Hussein Onn \\ Malaysia, Pagoh Educational Hub, Johor, Malaysia \\ ${ }^{2}$ Centre of Advanced Research for Integrated Solid Waste Management (CARISMA) \\ Faculty of Civil and Environment Engineering, Universiti Tun Hussein Onn Malaysia, Johor, Malaysia \\ ${ }^{3}$ Faculty of Technical and Vocational Education, Universiti Tun Hussein Onn Malaysia, Johor, Malaysia \\ ${ }^{4}$ School of Industrial Technology, Universiti Sains Malaysia, Gelugor 11800, Malaysia.
}

Received 14 March 2018; accepted 12 December 2018, available online 29 December 2018

\begin{abstract}
Leachate is a liquid generated due to rainwater percolation through the wastes in a landfill or dumping site that may contain high levels of organic matter including both biodegradable and non-biodegradable which major source of water pollution. In this research work, landfill leachate has been characterized and found to contain very high COD and color. Adsorption process was performed to find out the performance of different combinations ratio between limestone (LS) and zeolite (ZEO). The removal efficiencies of different ratios were examined for reduction of COD and color. The optimum mixture ratio of adsorbents (LS:ZEO) at 10:30 and 15:25 were found to be more effective in reducing COD and color respectively as compared with the use of individual media. The highest removal percentage were found at approximately 55\% of COD and $76 \%$ of color with 120 minutes of contact time, $200 \mathrm{rpm}$ in shaking speed at $\mathrm{pH} 7$. The Langmuir adsorption isotherm model exhibited a better fit with high correlation $\mathrm{R}^{2}=0.9991$ for $\mathrm{COD}$ and $\mathrm{R}^{2}=0.9827$ for (color) respectively, which implies that the adsorption of leachate in this study onto LS-ZEO is homogeneous with monolayer. It was observed that limestone and zeolite mixture provides an alternative medium for removing COD and color at a considerably lower cost.
\end{abstract}

Keywords: Limestone, Zeolite, Composite, COD, Color, Adsorption

\section{Introduction}

Landfills is the most common techniques to organize waste disposal in many places around the world. It is the most economical and environmentally acceptable technique for eliminating and disposing municipal and industrial solid wastes [1]-[4]. Landfill leachates usually may contain high load of organic matter including both biodegradable and non-biodegradable, high ammonia nitrogen content, heavy metals, inorganic salts, and chlorinated organics [2]. When a highly contaminated landfill leachate is directly discharged into the environment, it may percolate through soils and subsoils, seriously threatening the public health, and ecosystem. Therefore, pollutants removal has become a very important concern in leachate treatment over recent decades [3].

There are many factors affecting the characteristics of landfill leachate such as age of landfill, hydrogeology of the site, quality and quantity of solid waste, site climate, season, biological and chemical processes occurring in the landfill, the amount of precipitation and percolation of rainwater, landfill morphology, waste depth, landfill condition, and operation of facilities [4]. Old (Stabilized) leachate characterized as a very low biodegradable value (biochemical oxygen demand [BOD]/chemical oxygen demand [COD] ratio which is difficult to biologically proceeds. The variation of biodegradability $\left(\mathrm{BOD}_{5} / \mathrm{COD}\right)$ in leachate was attributed to the different types of leachate that were categorized based on landfill age and leachate decomposition. Generally, $\mathrm{BOD}_{5} / \mathrm{COD}$ ratio of young ( $<1$ years), intermediate (1-5 years), and stabilized ( $>5$ years) leachate was reported as $0.5-1.0,0.1-0.55$, and $<0.1$, respectively [5].

Adsorption is a relatively simple physico-chemical technique and may be employed successfully for the treatment of stabilized landfill leachates. Basically, adsorption is a mass transfer process by which a substance is transferred from the liquid phase to the surface of a solid, and becomes bound by physical and chemical interactions. Today, there has been an increases focus on the use of low-cost materials (e.g., agricultural waste or natural polymers and by-products of industrial processes) to achieve appropriate leachate treatment or as 
an alternative approach to conventional adsorbent for water and wastewater treatment due to its availability in local places and environmentally friendly materials.

Application of adsorbents based on zeolite has certain benefits over conventional methods applied for the water and wastewater treatment. Zeolite is naturally hydrated aluminosilicate mineral that belongs to mineral class "tectosilicates" and highly porous material [6]. It has a natural negative charge which gives it the capacity to adsorb cations. Zeolites have great potential as effective adsorbents in numerous processes of purification of drinking water and wastewater [7], removal of ammoniacal nitrogen $\left(\mathrm{NH}_{3}-\mathrm{N}\right)$, dissolved organic matter, color, heavy metals from landfill leachate [8], [9], and many others.

It has been reported that mixture of zeolite and limestone could effectively remove color and $\mathrm{NH}_{3}-\mathrm{N}$, COD and Fe from landfill leachate [8], [9]. The use of limestone and zeolite in leachate treatment is not well established. Rosli [9] state that composite material has also been developed for many purposes, such as improving adsorptive properties or producing low-cost adsorbents. In line with the above, this study has combined two types of minerals to improve the adsorption properties and minimizing the treatment cost by substituting partially of zeolite with limestone. The effect of zeolite and limestone ratio toward COD and color removal efficiency are investigated throughout this study. This was obtained by identifying the optimum composition of the adsorbate medium using batch technique. Also, the Langmuir and Freundlich models were used to analyze the adsorption equilibrium. Thus, the results would be useful in establishing the removal pattern of each parameter in landfill leachate.

\section{Materials and Method}

\subsection{Landfill Leachate Sampling}

The sampling method for leachate from Simpang Renggam Landfill was in accordance with procedures described in Standard Methods for the Examination of Water and Wastewater [10]. Leachate was obtained manually from a pond in 20 -L high-density polyethylene plastic containers. The samples were immediately transported to the laboratory and stored in a cold room at $4^{\circ} \mathrm{C}$ prior to experimental use to minimize biological and chemical reactions. All reagents used in this study were of analytical grade. The characteristics of the leachate are illustrated in Table 1.

\subsection{Preparation of Adsorbents}

Limestone and zeolite (clinoptilolite) used in this study were purchased from marble factory and PT. Anugerah Alam Sdn. Bhd. respectively. The preparation was conducted according to the procedure outlined by [8], [9]. Media density was determined conventionally (i.e., weight per volume of media). Both limestone and zeolite were ground to obtain a particle size of less than $150 \mu \mathrm{m}$ using ceramic ball mill.

\subsection{Optimum Ratio}

The optimum ratio between limestone and zeolite in this study were determined based on previous researcher proposed for various amounts (by weight) [9]. Different range of selected mixture ratios of LS and ZEO were used i.e. $0: 40,5: 35,10: 30,15: 25,20: 20,25: 15,30: 10,35: 5$, and 40:0. The batch equilibrium experiments were conducted by mixing a fixed amount of media (as mentioned above) with $100 \mathrm{~mL}$ of raw leachate sample in a $250 \mathrm{~mL}$ conical flask at $\mathrm{pH} 7$, agitation speed $200 \mathrm{rpm}$, and 120 minutes contact time. The optimum mixture ratios were determined which reveal in terms of achievable maximum removal of COD and color parameters. Three replicates per sample were done and the average results were used. The removal efficiencies of COD and color in the solution was evaluated by using Eq. (1).

$E(\%)=\left[100\left(C_{i}-C_{f}\right) / C_{i}\right]$

where, $C_{i}$ and $C_{f}$ are the initial and the equilibrium of all parameters concentrations of leachate in $\mathrm{mg} / \mathrm{L}$, respectively.

\subsection{Adsorption Equilibrium}

The isotherm experiments were carried out by contacting $4.0 \mathrm{~g}$ of the LS-ZEO adsorbents with $100 \mathrm{~mL}$ of different leachate concentrations (100 to 10-degree dilution) in $250 \mathrm{~mL}$ conical flask allowing sufficient time, $120 \mathrm{~min}$, for adsorption equilibrium. The amount of adsorbed LS-ZEO (mg/g) was calculated based on a mass balance equation as given by the following equation (2):

$q_{e}=\left(C_{o}-C_{e}\right) V / m$

where, $q_{e}$ is the equilibrium sorption capacity $(\mathrm{mg} / \mathrm{g}), C_{o}$ and $C_{e}$ is the initial and equilibrium COD and color concentrations in the leachate $(\mathrm{mg} / \mathrm{L}), m$ is the mass of used LS-ZEO adsorbents $(\mathrm{g})$, and $V$ is the volume of the leachate solution $(L)$. In order to describe the relationship between the amount of COD and color, Langmuir and Freundlich models were applied.

\subsection{Adsorption Isotherm Models}

The adsorption equilibrium data for COD and color on LS-ZEO were analyzed in terms of the Langmuir [11] and Freundlich [12] adsorption isotherm models.

The conventional Langmuir parameters were obtained by fitting the experimental data to the linearized equation derived from equation (3):

$1 / q_{e}=\left[1 / q_{m} K_{L}\right] 1 / C_{e}+1 / q_{m}$ 
The parameters of $q_{m}$ and $K_{L}$ were obtained from the slope and intercept of the Langmuir plot of $1 / q_{e}$ vs $1 / C_{e}$ respectively.

The Freundlich parameters were obtained by fitting the experimental data to the linearized equation derived from equation (4):

$\ln q_{e}=\ln K_{F}+1 / n \ln C_{e}$

The parameters of $K_{F}$ and $n_{F}$ obtained from the intercept and slope of the Freundlich plot of $\ln q_{e}$ vs $\ln C_{e}$ respectively.

In order to predict the adsorption efficiency of the favorability of adsorption process, dimensionless parameter of the equilibrium known as separation factor, $S_{F}$ was determined by using the following equation (5):

$S_{F}=1 / 1+K_{L} C_{o}$

There are four probabilities for the $S_{F}$ values that indicates the adsorption nature to be unfavourable $\left(S_{F}>\right.$ $1)$, linear $\left(S_{F}=1\right)$, favourable $\left(0<S_{F}<1\right)$ or irreversible $\left(S_{F}=0\right)[11]$.

\subsection{Leachate Analysis}

COD concentration was determined using closed reflux and Colorimetric Method (5220-D). Color measurement was reported as true color assayed at 455 $\mathrm{nm}$ using a HACH/DR6000 spectrophotometer and reported as platinum-cobalt $(\mathrm{Pt}-\mathrm{Co})$ method, the unit of color being produced by $1 \mathrm{mg}$ platinum/L in the form of chloroplatinate ion. The samples were filtered using 0.45 $\mu \mathrm{m}$ filter paper before each measurement. All methods were adapted from the Standard Methods for the Examination of Water and Wastewater [10]. All tests were conducted in triplicates to obtain consistent results at room temperature $25 \pm 2^{\circ} \mathrm{C}$.

\section{Results and Discussion}

\subsection{Leachate Characteristics}

Leachate sample were collected from the pond of landfill site and analyzed to determine the initial content of pollutants such as COD, pH, BOD5, color, suspended solids, NH3-N, and iron (Fe). The characteristics of leachate are illustrated in Table 1. The $\mathrm{pH}$ value of these samples was about $8.05-8.32$, with rather high nonbiodegradable organic content $($ BOD5 $=156-329 \mathrm{mg} / \mathrm{L}$; $\mathrm{COD}=2440-2990 \mathrm{mg} / \mathrm{L})$, which corresponds to the average BOD5/COD ratio of 0.09 . It is apparent that the collected samples may be classified as stabilized or old leachate [13]. Thus, adsorption may work well for this type of leachate [14].
Table 1 Characteristics of raw leachate from Simpang

Renggam Landfill Site

\begin{tabular}{cccccc}
\hline Parameter & \multicolumn{3}{c}{ Values } & $\begin{array}{c}\text { Std. } \\
\text { Dev. }\end{array}$ & $\begin{array}{c}\text { MEQA } \\
{[15]}\end{array}$ \\
\hline & Min. & Max. & Ave. & & \\
\hline $\mathrm{pH}$ & 8.05 & 8.32 & 8.19 & 0.11 & $6.0-9.0$ \\
$\mathrm{SS}(\mathrm{mg} / \mathrm{L})$ & 143 & 213 & 177.22 & 22.63 & 50 \\
$\mathrm{NH}_{3}-\mathrm{N}$ & 1555 & 2010 & 1765.34 & 190.54 & 5 \\
$(\mathrm{mg} / \mathrm{L})$ & & & & & \\
$\mathrm{COD}(\mathrm{mg} / \mathrm{L})$ & 2440 & 2990 & 2739.06 & 225.68 & 400 \\
$\mathrm{BOD}_{5}(\mathrm{mg} / \mathrm{L})$ & 156 & 329 & 249.45 & 61.51 & 20 \\
$\mathrm{BOD}_{5} / \mathrm{COD}$ & 0.06 & 0.12 & 0.09 & 0.02 & - \\
$\mathrm{Fe}(\mathrm{mg} / \mathrm{L})$ & 6.45 & 8.94 & 7.19 & 0.93 & 5.0 \\
Color $(\mathrm{Pt}-\mathrm{Co})$ & 4061 & 4748 & 4539.56 & 260.00 & - \\
\hline & & & & &
\end{tabular}

\subsection{Optimum Ratio}

\subsubsection{Effect of Different Ratio Towards COD}

See Fig. 1. The figure shows COD-removal efficiency against different ratios of limestone and zeolite. More than $42 \%$ of COD with an intensity of up to $2990 \mathrm{mg} / \mathrm{L}$ was removed from the stabilized landfill leachate with ZEO as the sole media. While, the using of LS alone (mixture ratio 40:0) produces the lowest result with $33 \%$ COD removal compared to individual media (ZEO alone at mixture ratio 0:40) and the several mixture ratios of both adsorbent. The minimum ratio of ZEO that achieved the greatest COD removal was considered as the optimum mixture. The result also indicates that the optimum ratio was at 10:30 (consist of $25 \%$ LS and $75 \%$ ZEO), where the removal percentage of COD remained constant (although the percentage of ZEO increased) with $55 \%$ of COD removal. In other words, about $25 \%$ of ZEO could be replaced by LS at maximum COD removal.

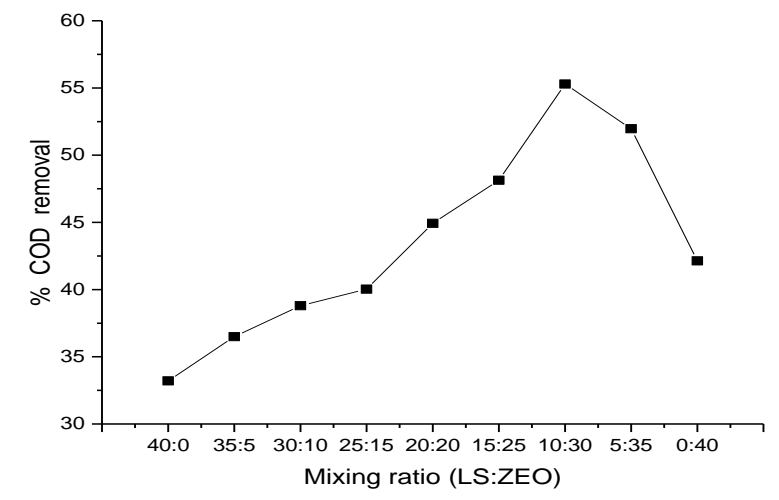

Fig.1 Percentage of COD removal against different ratios of limestone and zeolite

\subsubsection{Effect of Different Ratio Towards Color}


See Fig. 2. The figure shows the color-removal efficiency corresponding to different ratios of limestone and zeolite.

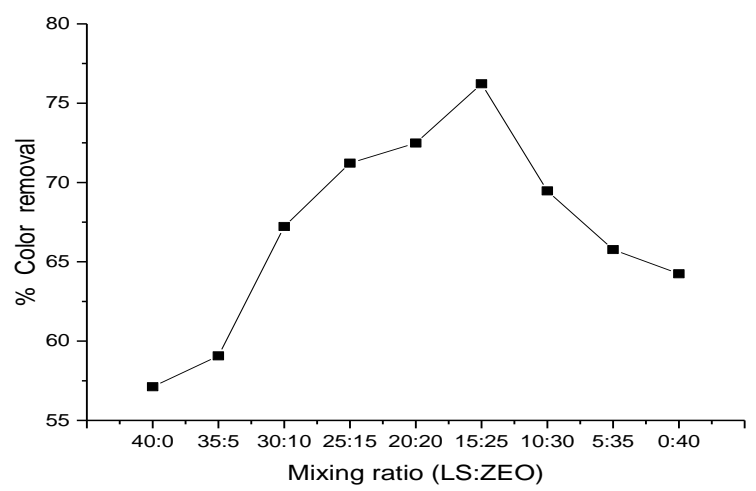

Fig.2 Percentage of color removal against different ratios of limestone and zeolite

From the Fig. 2, the minimum ratio of ZEO that achieved the highest color removal was considered as the optimum mixture. More than $76 \%$ of color with an initial concentration of $4748 \mathrm{mg} / \mathrm{L}$ was removed by a combination of LS-ZEO adsorbent at mixing ratio 15:25 by weight, where consist of $37.5 \%$ LS and $62.5 \%$ ZEO that considered as an optimum ratio. There will be no increased in the percentage of color removal after increasing the percentage of ZEO. At the maximum color removal, this ratio is taken as the optimum replacement and approximately $37.5 \%$ of ZEO could be replaced by LS. However, the using of LS alone (mixture ratio 40:0) did not produce satisfactory results with less than $58 \%$ COD removal.

Aziz was reported that color is a common pollutant in landfill leachate [16]. Classically, stabilized leachate contains high levels of organic substances such as humic and fulvic compounds, which can be indicated by leachate color that may cause the water to turn yellow, brown, or black. COD is defined as the amount of oxygen required to completely oxidize organic constituents to carbon dioxide and water [17]. The decrease in $\mathrm{BOD}_{5} / \mathrm{COD}$ ratio results also in the decrease of treatment efficiency [18-28]. The findings of current study are in accordance with those stated in literature [6], [18]. COD and color treatment efficiency is clearly enhanced by using combination of LS and ZEO for both parameters removal as compared to individual media only.

\subsection{Adsorption Isotherm}

See Fig. 3. The figure shows the plots of COD and color onto LS-ZEO for Langmuir and Freundlich isotherms. The coefficient and parameters of determination, $\mathrm{R}^{2}$ are shown in Table 2.

As can be seen from Fig. 3, the Langmuir isotherm fits the data better than Freundlich isotherm. This is also confirmed by the high value of regression coefficient $\left(\mathrm{R}^{2}\right)$ in case of Langmuir (0.9991) for COD and (0.9827) for color compared to Freundlich (0.9894) for COD and
(0.9679) for color, and these indicate that the adsorption of both parameters onto LS-ZEO takes place as monolayer adsorption on a surface that is homogenous in adsorption affinity, where the maximum uptake capacity $\left(q_{m}\right)$ of COD and color were $41.32 \mathrm{mg} / \mathrm{g}$ and $20.62 \mathrm{mg} / \mathrm{g}$ respectively (Table 2). In the present study the value of $n$ was higher than the unity, indicating that the adsorption process was favourable under the studied conditions. The $S_{F}$ values for the adsorption of COD and color onto LSZEO are in the range of 0.0370-0.9727 (Figure not shown), representing that the adsorption is a favourable process and that at high initial COD and color concentrations the adsorption is nearly irreversible. This is an agreement with similar finding reported by other researchers [8], [11].

Table 2 Langmuir and Freundlich adsorption isotherm parameters

\begin{tabular}{ccccccc}
\hline & Langmuir & \multicolumn{5}{c}{ Freundlich } \\
& $q_{m}$ & $K_{L}$ & $\mathrm{R}^{2}$ & $n$ & $K_{F}$ & $\mathrm{R}^{2}$ \\
& $(\mathrm{mg} / \mathrm{g})$ & $(\mathrm{L} / \mathrm{mg})$ & & & & \\
COD & 41.32 & $\begin{array}{c}9.39 \mathrm{x} \\
10^{-4}\end{array}$ & 0.9991 & 1.09 & $\begin{array}{c}5.10 \times \\
10^{-2}\end{array}$ & 0.9894 \\
& & & & $n$ & $K_{F}$ & $\mathrm{R}^{2}$ \\
& $q_{m}$ & $K_{L}$ & $\mathrm{R}^{2}$ & $n$ & & \\
Color & $(\mathrm{mg} / \mathrm{g})$ & $(\mathrm{L} / \mathrm{mg})$ & & & $1.41 \times$ & 0.9679 \\
& 20.62 & $5.48 \mathrm{x}$ & 0.9827 & 1.19 & $10^{-1}$ & \\
\hline
\end{tabular}

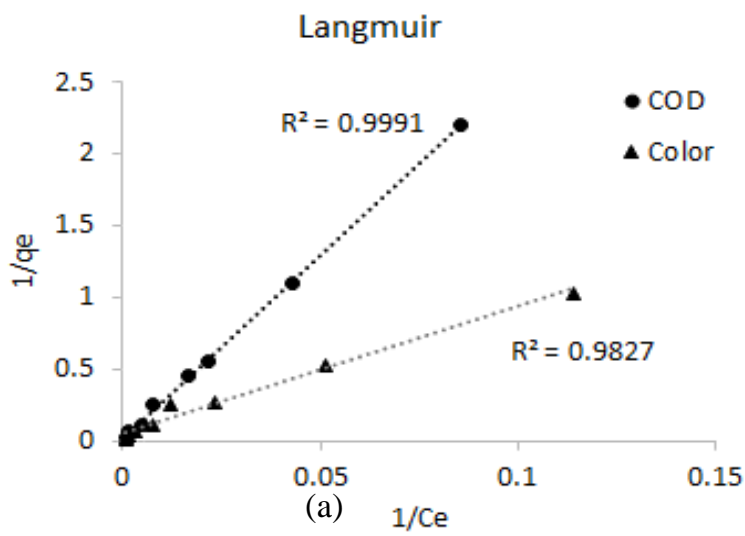




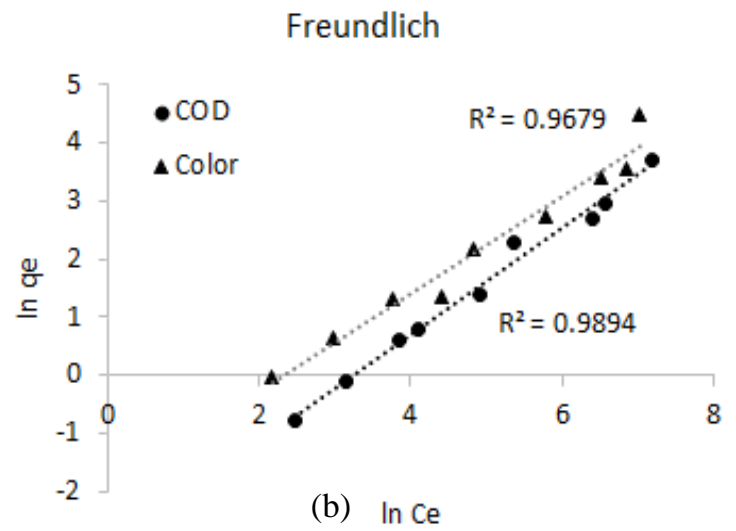

Fig.3 Plots of (a) Langmuir and (b) Freundlich isotherms for COD and color adsorption onto LS-ZEO

\section{Summary}

In this study, the result showed that limestone and zeolite combination was shown the capability for removal COD and color from stabilized landfill leachate. It should be noted that the best mixture ratio of LS and ZEO at 10:30 with the maximum COD removal of $55 \%$ whereas $15: 25$ with the maximum color removal of $76 \%$. The equilibrium data were fitted to the Langmuir and Freundlich isotherm models. The Langmuir model best fitted the equilibrium data over the entire concentration range studied. The obtained adsorption capacity for the COD and color were a good indicator of the LS-ZEO potential for its use in the adsorption system. Therefore, for further works, adsorption kinetic is suggested to be taken into account to investigate the adsorption processes of COD and color onto LS-ZEO.

\section{Acknowledgements}

The authors would like to express their gratitude to the Ministry of Higher Education Malaysia (MyBrain15$\mathrm{MyPhD}$ ) and Universiti Tun Hussein Onn Malaysia for the financial assistance.

\section{References}

[1] Daud, Z., Nasir, N., Aziz Abdul Latiff, A., Ridzuan, M. B., \& Awang, H., Treatment of Biodiesel Wastewater by Coagulation-flocculation Process Using Polyaluminium Chloride (PAC) and Polyelectrolyte Anionic. ARPN Journal of Engineering and Applied Sciences, Volume 11(20), (2016), pp. 11855-11859.

[2] Bashir, M.J.K., Aziz, H.A., Yusoff, M.S., and Aziz, S.Q., Color and chemical oxygen demand removal from mature semi-aerobic landfill leachate using anion-exchange resin: an equilibrium and kinetic study, Environmental Engineering Science, Volume 29, Issue 5, (2012), pp. 297-305.
[3] Daud, Z., Aziz, H.A., Adlan, M.N., and Hung Y.T., Application of combined filtration and coagulation for semi-aerobic leachate treatment, International Journal of Environment and Waste Management, Volume 4, Issues 3/4, (2009), pp. 457-469.

[4] Daud, Z., Abubakar, M.H., Kadir, A.A., Latiff, A.A., Awang, H., Halim, A.A., Marto, A., Optimization of leachate treatment with granular biomedia: Feldspar and Zeolite. Indian Journal of Science and Technology, Volume 9(37), (2016), 91845.

[5] Alvarez-Vazquez, H., Jefferson, B., and Judd S.J., Membrane bioreactors vs. conventional biological treatment of landfill leachate: a brief review, Journal of Chemical Technology and Biotechnology, Volume 79, Issue 10, (2004), pp. 1043-1049.

[6] Latiff, A. A. A., Adeleke Abdul Rahman, O., Daud, Z., Ridzuan, M. B., \& Mat Daud, N. F., Batch Adsorption of Manganese from Palm Oil Mill Effluent Onto Activated Cow Bone Powder. ARPN Journal of Engineering and Applied Sciences, Volume 11(4), (2016), pp. 2627-2631.

[7] Lakdawala, M.M., and Patel, Y.S., Studies on adsorption capacity of zeolite for removal of chemical and bio-chemical oxygen demands, Chemistry Journal, Volume 1, Issue 4, (2015), pp. 139-143.

[8] Aziz, H.A., Foul, A.A., Isa, M.H., and Hung, Y.T., Physico-chemical Treatment of Anaerobic Landfill Leachate using activated carbon and zeolite: batch and column studies, International Journal Environment and Waste Management, Volume 5, Issues 3/4, (2010), pp. 269-285.

[9] Rosli, M.A., Daud, Z., Latiff, A.A.A., A Rahman, S.E., Oyekanmi, A.A., Zainorabidin, A., Awang, H., and Halim A.A., The effectiveness of peat-ac composite adsorbent in removing color and $\mathrm{Fe}$ from landfill leachate, International Journal of Integrated Engineering, Volume 9, Issue 3, (2017), pp. 35-38.

[10] Standard Methods for The Examination of Water and Wastewater. Washington, DC: American Public Health Association (APHA), 2012.

[11] Adeleke, A. R. O., Abdul Latiff, A. A., Daud, Z., Ridzuan, B., and Mat Daud, N. F., Remediation of Raw Wastewater of Palm Oil Mill Using Activated Cow Bone Powder through Batch Adsorption. Key Engineering Materials, 705, (2016), pp. 380-384.

[12] Halim, A.A., and Ahmad, M.F., Isotherm and kinetic adsorption of boron onto limestone as a low-cost adsorbent, Sains Malaysiana, Volume 42, Issues 12, (2013), pp. 1689-1696.

[13] Nasir, Z. and Daud, Z., Performance of Aluminium Sulphate and Polyaluminium Choloride In Biodiesel Wastewater. Journal of Mechanical Engineering and Sciences, Volume 7(1), (2014), pp. 1189-1195. 
[14]Daud, Z., Abubakar, M.H., Kadir, A.A., Latiff, A.A.A., Awang, H., Halim, A.A. \& Marto, A., Adsorption studies of leachate on cockle shells. International Journal of GEOMATE, Volume 12(29), (2017), pp. 2186-2990.

[15] Environmental Quality (Control of Pollution from Solid Waste Transfer Station and Landfill) Regulations 2009; Under the Laws of MalaysiaMalaysia Environmental Quality Act 1974; Department of Environment: Kuala Lumpur, Malaysia, 2010.

[16] Aziz, H.A., Hin, L.T., Adlan, M.N., Zahari, M.S., Alias, S., Abufoul, A.A.M., Selamat, M.R., Bashir, M.J.K., Yusoff, M.S., and Umar M., Removal of high-strength colour from semi-aerobic stabilized landfill leachate via adsorption on limestone and activated carbon mixture, Research Journal of Chemical Sciences. Volume 1, Issue 6, (2011), pp. 17.

[17] Burton, F.L., Tchobanoglous, G., and Stensel, H.D., Wastewater Engineering: Treatment and Reuse, $4^{\text {th }}$ edition, Metcalf and Eddy Inc., McGraw Hill Higher Education, 2002.

[18] Halim, A.A., Aziz, H.A., Megat Johari, M.A., Ariffin K.S., and Bashir, M.J.K., Semi-aerobic landfill leachate treatment using carbon-minerals composite adsorbent, Environmental Engineering Science, Volume 29, Issue 25, (2012), pp. 306-312.

[19] Daud, Z., Awang, H., Kassim, A.S.M., Hatta, M.Z.M. \& Aripin, A.M., Comparison of pineapple leaf and cassava peel by chemical properties and morphology characterization. Advanced Materials Research. Volume 974, (2014), pp. 384-388.

[20] Daud, Z., Suhani, N., Mohamed, R.M.S.R., Awang, H., Feasibility of banana (Musa sapientum) trunk biofibres for treating kitchen wastewater. Nature Environment and Pollution Technology, Volume 16 (4), (2017), pp. 1205-1210.

[21] Wang, F., Abdullah, A.H. Investigating thermal conditions in a tropic atrium employing CFD and DTM techniques. International Journal of LowCarbon Technologies, Volume 6 (3), (2011), art. no. ctr005, pp. 171-186.

[22] Antonyová, A., Antony, P., Abdullah, A.H., Nagapan, S., Daud, Z., Abubakar, M.H. Certain building materials with respect to their thermal properties as well as to their impact to environment. International Journal of Integrated Engineering, Volume 10 (4), (2018), pp. 126-130.

[23] Aminudin, E., Md Din, M.F., Hussin, M.W., Abdullah, A.H., Iwao, K., Ichikawa, Y. Properties of agro-industrial aerated concrete as potential thermal insulation for building. MATEC Web of Conferences, Volume 47, (2016) art. no. 04020.

[24] Yunus, R., Abdullah, A.H., Yasin, M.N., Masrom, M.A.N., Hanipah, M.H. Examining performance of Industrialized Building System (IBS) implementation based on contractor satisfaction assessment. ARPN Journal of Engineering and Applied Sciences, Volume 11 (6), (2016), pp. 3776-3782.

[25] Bakar, S.K.A., Abdullah, A.H. Simulation of thermal performance in an office building. BEIAC 2012 2012 IEEE Business, Engineering and Industrial Applications Colloquium, art. no. 6226074, (2012), pp. 318-323.

[26] Balakrishnan, B., Awal, A.S.M.A., Abdullah, A.B., Hossain, M.Z. Flow properties and strength behaviour of masonry mortar incorporating high volume fly ash. International Journal of GEOMATE, Volume 12 (31), (2017), pp. 121-126.

[27] Al-Gheethi, A.A., Mohamed, R.M.S.R., Efaq, A.N., Norli, I., Halid, A.A., Amir, H.K., Kadir, M.O.A. Bioaugmentation process of secondary effluents for reduction of pathogens, heavy metals and antibiotics. Journal of Water and Health, Volume 14 (5), (2016), pp. 780-795.

[28] Sohu, S., Abd Halid, A., Nagapan, S., Fattah, A., Latif, I., Ullah, K. Causative factors of cost overrun in highway projects of Sindh province of Pakistan. IOP Conference Series: Materials Science and Engineering, Volume 271 (1), (2017), art. no. 012036. 